\title{
DNA Barcodes Identify Medically Important Tick Species in Canada
}

\begin{tabular}{|r|l|}
\hline Journal: & Genome \\
\hline Manuscript ID & gen-2015-0179.R1 \\
\hline Manuscript Type: & Article \\
\hline Date Submitted by the Author: & 09-Mar-2016 \\
\hline Complete List of Authors: & $\begin{array}{l}\text { Ondrejicka, Danielle; University of Guelph, Biodiversity Institute of Ontario } \\
\text { Morey, Kevin; University of Guelph, Biodiversity Institute of Ontario } \\
\text { Hanner, Robert; University of Guelph, Biodiversity Institute of Ontario }\end{array}$ \\
\hline Keyword: & $\begin{array}{l}\text { COI, tick identification, DNA Barcoding, Borrelia burgdorferi, cryptic } \\
\text { diversity }\end{array}$ \\
\hline
\end{tabular}

\section{SCHOLARONE ${ }^{m}$ \\ Manuscripts}


Title: DNA Barcodes Identify Medically Important Tick Species in Canada

Running Title: DNA barcodes identify ticks in Canada

By: Danielle A. Ondrejicka ${ }^{1}$, Kevin C. Morey ${ }^{1}$ and Robert H. Hanner ${ }^{1 *}$

${ }^{1}$ Department of Integrative Biology, University of Guelph, Guelph, N1G 2W1, Ontario, Canada

Correspondence: Via mail: Dr. Robert H. Hanner, Biodiversity Institute of Ontario, University

of Guelph, 50 Stone Road East, Guelph, ON, Canada, N1G 2W1

Via email: rhanner@uogeulph.ca

Via fax: 1-519-824-5703 


\begin{abstract}
Medically important ticks (Acari: Ixodidae) are often difficult to identify morphologically. A standardized, molecular approach using a 658 base pair DNA barcode sequence (from the 5' region of the mitochondrial cytochrome $c$ oxidase subunit I gene) was evaluated for its effectiveness in discriminating ticks in North America, with an emphasis on Canadian ticks. DNA barcodes were generated for 96 of 154 specimens representing 26 ixodid species. A genetic cluster analysis was performed on the barcode sequences, which separated specimens into haplogroups closely corresponding with morphologically identified species. The tree topology was further supported by a BIN analysis. COI sequences generated were found to have a mean maximum intraspecific divergence of $1.59 \%$ and a mean nearest neighbour divergence of $12.8 \%$, indicating a significant "barcode gap". This study also revealed possible cryptic diversity among specimens morphologically identified as Ixodes soricis and Ixodes texanus. A PCR-based test for Borrelia burgdorferi determined that $18.1 \%$ of Lyme-competent ticks in this study were positive. This study is also the first to record a B. burgdorferi-positive exoskeleton. In conclusion, DNA barcoding is a powerful tool that clinicians can use to determine the identification of tick specimens which can help them to suggest whether an attached tick is a potential health risk.
\end{abstract}

Keywords: Borrelia burgdorferi, COI, cryptic diversity, tick identification, DNA barcoding 


\section{Introduction}

The family Ixodidae, the hard-bodied ticks, is comprised of 702 species within 14 genera (Guglielmone et al. 2010) and includes species capable of transmitting bacterial, viral, and protozoan pathogens to their animal and human hosts. One of the most common tick-borne zoonotic diseases in Canada is Lyme disease, caused by the spirochete bacteria Borrelia burgdorferi. In North America, the primary vectors of B. burgdorferi include Ixodes scapularis and I. pacificus; meanwhile, I. affinis, I. dentatus, I. spinipalpis (Eisen and Lane, 2006), and I. muris (Dolan et al. 2000) are also suitable vectors. A study published by Besansky et al. (2003) argues that taxonomic revisions should focus on vectors, such as ticks, that are responsible for the spread of medically relevant pathogens and that the use of DNA-based approaches for species discrimination should be incorporated into these revisions.

Traditionally, ticks have been identified morphologically. However, difficulties can arise due to significant variation within larval, nymphal, and adult tick life stages. The immature stages (larvae and nymphs) are the most difficult to identify (Anderson et al. 2004). These specimens have minuscule physical characteristics that are hard to distinguish even with a stereoscopic microscope. Further difficulty ensues if the ixodid tick is engorged or if the specimen has been disfigured, which often occurs when removing a tick from its host (Anderson et al. 2004). The aforementioned difficulties with identification are compounded by the fact that the most recent morphological key for ixodid ticks in Canada was published over 50 years ago (see Gregson, 1956). This key is now incomplete based on current knowledge of tick diversity and distribution in the country.

A DNA-based approach to specimen identification of ixodid ticks is advantageous in that it can be used to identify immature ticks and destroyed samples to species level. The DNA barcode methodology represents a prime candidate to undertake this task as it is the most comprehensive initiative of all the DNA-based approaches (IBOL.org). DNA barcoding uses short, standardized gene sequences for specimen identification and species discovery (Herbert et al. 2003a). For animals, the standard barcode 
consists of 658 base pair (bp) of the 5' region of the mitochondrial cytochrome $c$ oxidase subunit I gene (herein referred to as the COI gene).

Another advantage of the DNA barcoding approach is the increased transparency and reproducibility of sequence data enabled by the Barcode of Life Data System (BOLD; www.barcodinglife.org), an online workbench for the management, analysis, and archival of barcode records that includes specimen images and the Barcode Index Number (BIN) framework for organizing records into species-like groupings and for delineating cryptic taxa (Ratnasingham and Hebert 2013).

A bioidentification system for all animals has been proposed using this gene, and scientists have successfully demonstrated its success for diverse taxonomic groups (Hebert et al. 2003b; Witt et al. 2006; Clarke et al. 2006) including various parasitic taxa (Ogedengbe et al. 2011; Webster et al. 2012; Cywinska et al. 2006) and even limited numbers of Ixodidae species (Barrett et al. 2005; Lv et al. 2013). A recent study of Ixodidae collected in China found that as a single gene identification system, COI was more effective at delineating Ixodidae species than $16 \mathrm{~S}$ or $18 \mathrm{~S}$ (Lv et al. 2013). A large-scale DNA barcode study of Ixodidae has not been undertaken in Canada or North America in general. In addition, the vast majority of publicly available tick barcodes on GenBank and BOLD are focused on the major vectors of Lyme disease.

Further development of molecular approaches may also prove useful for detecting both the host species and the presence of infection, contributing to public health by improving diagnoses and in epidemiological studies. Once barcoded, Lyme-competent vector ticks in this study were screened for systemic infection of B. burgdorferi using a nested PCR-based assay. This test is specific for the OspA gene, which encodes an outer surface protein of B. burgdorferi (Matuschka et al. 1996).

The objectives of this study were to 1) construct a DNA barcode library for Ixodidae in Canada based on morphologically identified specimens; 2) assess the prospect of a DNA barcode-based specimen identification system for the identification of medically relevant ticks compared to the morphological 
identification of tick specimens to species, through the quantification of intraspecific and interspecific genetic variability; and 3) assess the ability to make species-level diagnoses for ticks and detect the presence of B. burgdorferi in Lyme-competent vectors from within the same genomic DNA sample. In doing so, this study aims to provide support for the use of DNA barcoding as a tool clinicians can use to make tick specimen identifications to assist in assessing potential health risks. In addition to its use as a tool for medical diagnostics, this tool would also help contribute to wider public health goals, including monitoring, the preparation of public health warnings, and in the conduction of epidemiological studies

\section{Methods}

Specimens:

A total of 163 specimens were obtained from either the Lyme Disease Association of Ontario (LDAO) or the Biodiversity Institute of Ontario, University of Guelph. 149 specimens were obtained from the LDAO and represent an accumulation of specimens derived from multiple projects carried out over the past two decades (1993-2012). The authors attempted to generate DNA barcodes for all the LDAO specimens following the protocols listed below. 14 specimens were obtained from the Biodiversity Institute of Ontario (BIO), which were collected during the 2010 BIOBus field season. The BIOBus is a mobile collection vehicle that travels to North America's parks each summer to collect specimens to DNA barcode (www.biobus.ca). The 14 BIO sequences were generated using standardized and published methods at their high-throughput facility. The majority of the specimens were collected primarily from Canada, with a few collected from mammalian hosts from the United States, Mexico, and Costa Rica (Figures 1 and 2).

Ixodid ticks were identified morphologically employing keys by Durden and Keirans (1996) as well as Keirans and Clifford (1978). Specimens from the LDAO collected prior to 2009 were stored in isopropyl alcohol, and those collected after 2009 were stored in 95\% ethanol. Specimens collected by the BIObus were store in $95 \%$ ethanol. Voucher specimen information, digital images, and all other relevant metadata 
available (e.g. parasite host species, method of collection, location of collection) were deposited in BOLD under the publicly accessible projects named "Ticks of North America (project code: TODO)" or "BIO Mammal Parasites (project code: CSBMP)." 96 of the collected specimens were of appropriate condition after use in this study for vouchering and have been deposited as voucher specimens in the Biodiversity Institute of Ontario arthropod collection.

\section{DNA Extraction, PCR Amplification and Sequencing}

Where possible, a single leg or single whole molted exoskeleton was used for molecular work. Whole genomic DNA was extracted from this sub-sample using a QIAGEN DNeasy Blood and Tissue kit (QIAGEN, Valencia, CA) or a XYTOGEN Insect Extraction kit (XYTOGEN, Perth, Australia) according to manufacturer's instructions to a final elution volume of $2 \mu$ l. Specimens which had extractions fail were attempted again using the identical protocol. PCR reaction volumes of $12.7 \mu$ included: $0.0625 \mu 1$ dNTPs, $0.625 \mu 1 \mathrm{MgCl}_{2}, 1.25 \mu 110 \mathrm{X}$ buffer, $6.25 \mu 110 \%$ trehalose, $0.06 \mu 1$ platinum taq, $0.1 \mu 1$ of each primer cocktail, and $2 \mu 1$ of template DNA. PCR primers were used in succession until successful amplification was achieved (Table 1): 1) LCO1490 and HCO2198 (Folmer et al. 1994), 2), LepF1 and LepR1 (Herbert et al. 2004), and 3) Lep Folmer cocktail. For those samples that failed to amplify, PCR primers were used to amplify two halves of the barcode region separately to be edited together to recreate the full barcode sequence (Table 1): C_LepFolF (LCO1490 and LepF1 cocktail) and C_ANTMR1D (RonIIdeg_R and AMR1deg_R cocktail) (Folmer et al. 1994, Hebert et al. 2004, Simon et al. 1994, and Smith et al. 2005) for the preceding half and MLepF1 and C_LepFolR (HCO2198 and LepR1 cocktail) (Hajibabaei et al. 2006, Folmer et al. 1994, and Hebert et al. 2004) for the following half. The PCR thermocycle profile for all reactions consisted of: 1 cycle of $94{ }^{\circ} \mathrm{C}$ for $1 \mathrm{~min} ; 5$ cycles of $94{ }^{\circ} \mathrm{C}$ for $5 \mathrm{~min}$, $45^{\circ} \mathrm{C}$ for $1.5 \mathrm{~min}$, and $72{ }^{\circ} \mathrm{C}$ for $1 \mathrm{~min}$; followed by 35 cycles of $94{ }^{\circ} \mathrm{C}$ for $1 \mathrm{~min}, 5{ }^{\circ} \mathrm{C}$ for $40 \mathrm{sec}$, and $72{ }^{\circ} \mathrm{C}$ for $1 \mathrm{~min}$; and a final cycle of $72{ }^{\circ} \mathrm{C}$ for $5 \mathrm{~min}$. PCR products were visualized on a $2 \%$ agarose gel using an E-Gel 96 Pre-cast Agarose Electrophoresis System (Invitrogen). Successful amplicons underwent forward and reverse sequencing reactions with the following reagents: $1 \mu 1$ of big dye, $1 \mu 1$ of 
5X SeqBuffer, $10 \mu 1 \mathrm{ddH}_{2} 0,1 \mu 1 \mathrm{PCR}$ primer, $1 \mu \mathrm{l}$ PCR template. The sequencing profile consisted of: initial hot start of $96^{\circ} \mathrm{C}$ for $2 \mathrm{~min}, 30$ cycles [denaturation at $96^{\circ} \mathrm{C}$ for $30 \mathrm{sec}$, annealing at $55^{\circ} \mathrm{C}$ for 15 sec, and extension at $60{ }^{\circ} \mathrm{C}$ for $4 \mathrm{~min}$ ]. The products of the sequencing reaction were bi-directionally sequenced using the Big Dye Terminator version 3.1 Cycle Sequencing Kit (Applied Biosystems, Inc., Mississauga, ON) on an ABI 3730 capillary sequencer.

\section{DNA Sequence Analysis}

Bi-directional sequence contig assemblies were created and edited using Sequencher version 4.8 (Gene Codes Corporation, Ann Arbor, MI). High quality sequences were subsequently aligned via the CLUSTAL W algorithm within MEGA version 6.06, and the alignment was translated to amino acids for verification of proper alignment against the Invertebrate Mitochondrial genetic code (Tamura et al. 2011). Contig assemblies were uploaded to BOLD along with the raw electropherogram files and primer sequences used to generate them. All sequences were pooled into one dataset on BOLD for analysis. Conspecific and congeneric genetic distances were calculated using the Kimura 2-parameter (K2P) model (Kimura, 1980) in BOLD 3.0. A neighbour-joining tree (Nei and Kumar, 2000) was constructed in MEGA 6.06 using the K2P model to visualize patterns of genetic divergence within and between barcode clusters.

To further examine the significance of barcode clusters, the Barcode Index Number (BIN) system was applied to all sequences longer than 500 base pairs (bp) within this study and more broadly against all specimens on BOLD. The BIN system assigns specimens from various studies to operational taxonomic units (OTUs) based on nucleotide variation in the COI gene using the RESL algorithm (Ratnasingham and Hebert, 2013). These OTU's are examined and species assignments are first deemed as concordant (if all specimens in one OTU have the same species assignment within the dataset) or discordant (if species assignments vary within one OTU). Next, BINS are further classified into 4 categories (MATCH, SPLIT, MERGE, or MIXURE). A MATCH occurs when all members of a species are placed in one discrete BIN 
with no other members. A SPLIT occurs when a single species clusters into multiple discrete BINS with no other members, often indicating cryptic diversity. A MERGE occurs when 2 or more species are placed in a single BIN together, which may indicate misidentifications or reveal that the species are indistinguishable through barcodes. Lastly, a MIXTURE occurs when a species has complex portioning with more than one SPLIT and MERGE.

Morphological assignments that did not match barcode clusters were subject to re-examination by an expert. The number of misidentifications were noted and corrected as a result of this iterative process.

\section{Testing for B. burgdorferi}

Once barcoded, 22 Lyme-competent vector ticks (eight Ixodes scapularis, three I. pacificus, two I. affinis, two I. dentatus, three I. spinipalpis, three I. muris, and one I. baergi) were screened for systemic infection of B. burgdorferi using a nested PCR based test. Only ticks belonging to the genus Ixodes were screened for B. burgdorferi as there have been no confirmed cases of Lyme-competency in ticks of other genera (Burgdorfer et al. 1982). The whole genomic extraction used in DNA barcoding was screened; therefore, the source of DNA was from the tick leg or exoskeleton. In addition, five I. scapularis exoskeletons that were not barcoded (due to repetition of species) were also tested for B. burgdorferi. Whole exoskeletons from freshly molted ticks were placed in 95\% ethanol within three days of molting. The nested PCR was specific for the gene encoding OspA of B. burgdorferi (Matuschka et al. 1996). Each PCR run included 2 positive controls collected from Lyme-endemic areas and 2 negative controls. Each PCR reaction totalled $15.7 \mu 1$ and included $0.0625 \mu 1 \mathrm{dNTPs}, 0.625 \mu 1 \mathrm{MgCl}_{2}, 1.25 \mu 110 \mathrm{X}$ buffer, $6.25 \mu 110 \%$ trehalose, $0.06 \mu 1$ platinum taq, $0.2 \mu 1$ of each primer cocktail, and $5 \mu 1$ of template DNA or $5 \mu 1$ of PCR product. For PCR primer sequences and position in the $O s p A$ gene, see Table 2. The PCR thermocycle profile included heating for $2 \mathrm{~min}$ at $95^{\circ} \mathrm{C}$ and 40 cycles as follows: 20 seconds denaturation at $95^{\circ} \mathrm{C}, 20$ seconds at $59^{\circ} \mathrm{C}$ for the first annealing reaction and $61^{\circ} \mathrm{C}$ for the nested reaction, and 20 seconds of extension at $72^{\circ} \mathrm{C}$ 
(Matuschka et al. 1996). PCR products were visualized on a 2\% agarose gel using an E-Gel 96 Pre-cast Agarose Electrophoresis System (Invitrogen).

\section{Results}

Species Barcoded and Barcode Quality

This study generated DNA barcodes for 25 morphologically identified species from 5 genera and one unknown Amblyomma specimen. Barcodes were successfully generated for $3.69 \pm 0.660$ (mean \pm SEM) specimens per species, with a range of 1 to 15 barcodes produced per species. The most extensive coverage was of the genus Ixodes, with 16 species barcoded, consisting of 1 to 9 specimens per species (Figure 3). Full length DNA barcodes (> $500 \mathrm{bp}$ ) were successfully recovered for 84 specimens and partial barcodes for 13 specimens out of a total of 167 specimens examined. The partial barcodes were primarily produced due to successful sequencing in only one direction. Thus, to ensure accuracy, part of the barcode was trimmed due to a large number of ambiguous bases. The edited sequences had no stop codons and well defined chromatogram peaks, suggesting the absence of pseudogene co-amplification. Nucleotide composition showed an AT bias within Ixodidae, with a mean of 38.07\% T, 29.07\% A, $18.43 \% \mathrm{C}$, and $14.2 \% \mathrm{G}$.

Upon examination of the sequencing results and consultation with ixodid tick experts, five cases of misidentified specimens were detected. Morphologically misidentified specimens (i.e., a Dermacentor occidentalis nymph, an Ixodes dentatus nymph, an Ixodes spinipalpis larva, an Amblyomma sabanerae nymph, and an Ixodes angustus larva) were subject to morphological re-examination and found to be Rhipicephalus sanguineus, Ixodes muris, Ixodes pacificus, Amblyomma imitator, and Ixodes soricis, respectively.

Once misidentifications were resolved and corrected, K2P analysis showed that all but two tick species (I. texanus and I. soricis) separated into distinct haplogroups or "barcode clusters" (Figure 3). These two species each contained 2 distinct clusters (clusters A through D as indicated in Figure 3), suggesting the 
presence of cryptic diversity. Notably, I. texanus cluster A consisted of 2 specimens with an average intracluster K2P divergence of $0.67 \%$ and an average pairwise divergence of $14.97 \%$ from cluster B. Ixodes texanus cluster B consisted of 4 specimens with an average intracluster K2P divergence of $0.64 \%$ (range $0-0.80 \%$ ). Secondly, I. soricis cluster C consisted of 2 specimens with an average intracluster K2P divergence of .29\%. The I. soricis cluster D consisted of 1 specimen with a mean K2P divergence of $4.29 \%$ from cluster C.

Due to the 2 I. texanus clusters exhibiting deep genetic divergence similar to that seen at the interspecific level (Figure 3), these specimens were morphologically reexamined by an expert. Upon morphological reexamination where information for which individuals sorted into which clusters was withheld, subtle but distinguishable patterns of morphological co-variation were noted between the 2 clusters. When morphological differences and significant genetic divergence are combined, the cryptic species hypothesis is strengthened.

A barcode gap analysis was conducted using the K2P distance model and MUSCLE alignment on the remaining 24 species with distinct haplogroups for sequences $\geq 500 \mathrm{bp}$ in length, which revealed a mean maximum intraspecific divergence of $1.59 \%$, with a range of $0-14.5 \%$, and a mean nearest neighbour divergence of $12.8 \%$, with a range of 3.6-17.94\% (Figure 4), suggesting that ixodid ticks display a substantial "barcode gap". The means and ranges of maximum intraspecific divergences within genera were additionally determined and are reported (Table 4). It is important to note that for 3 species (Ixodes baergi, Ixodes marxi, Amblyomma tuberculatum) only one DNA barcode was generated, and no other reference sequences were publicly available; therefore, the reliability of DNA barcoding for identifying these 3 species cannot be assessed.

To further investigate the barcode clusters generated by the neighbour-joining tree, the BIN system analysis was computed for 90 of the 96 sequences on June $1^{\text {st }}, 2015$. Six sequences did not have sufficient length to be included in this analysis $(<500 \mathrm{bp})$. These 90 sequences were placed in 28 BINS, with 23 
BINS containing more than one specimen along with 4 singleton BINS. When these 28 BINS were computed against all other BIN records on BOLD at the time of writing, one instance of discordance was observed. This discordant BIN contained 48 members, with 47 Rhipicephalus sanguineus sequences and one R. leporis sequence. When the BIN analysis is examined at a species level, it further supports the neighbour-joining tree as BIN assignments are congruent with haplotypes on the tree. This analysis revealed the Ixodes texanaus and Ixodes soricis species were categorized as SPILTS, further supporting the hypothesis of cryptic diversity. In addition, the BIN system was utilized to identify the unknown Amblyomma specimen to the species Amblyomma tapirellum, whereas it had previously been identified to genus only based on morphology.

\section{B. burgdorferi Testing Results}

Lyme-competent ticks were screened for systemic infection of B. burgdorferi. 17 successfully barcoded ticks were tested in addition to 5 non-barcoded exoskeletons (whose species identities were known). Of 22 ticks tested, 4 (18\%) were positive for systemic B. burgdorferi infection (Table 3). Of all specimens tested, only I. scapularis ticks were found to test positive, of which $50 \%$ of specimens assessed tested positive for the presence of B. burgdorferi.

\section{Discussion}

This study represents the first effort at creating a reference DNA barcode library based on morphologically identified tick specimens in Canada. In addition, this study significantly increases the diversity of Ixodidae species represented on BOLD, as it added 21 unrepresented species to BOLD. A limitation of this study was the incomplete representation of all Ixodidae species in Canada, being able to only include 24 of the approximately 40 species known to occur in Canada (Canadian Lyme Disease Foundation 2016).

This study further demonstrates the ability of DNA barcodes to effectively discriminate tick species due to the presence of a substantial "barcode gap," with the minimum pairwise distance to the nearest 
neighbouring species being $8 \mathrm{x}$ greater than the mean maximum intraspecific distance. In addition to the barcode gap, there was no overlap seen between intra and interspecies variation.

DNA barcoding also has the ability to reveal interesting findings that can be difficult or impossible to reveal through morphological examination. Firstly, DNA barcoding revealed 5 morphological misidentifications, which demonstrates the difficulty, even for experts, in identifying immature life stages, and the utility of DNA barcoding to aid in these challenging specimen identifications. Secondly, this study revealed two cases of deep genetic divergence in species morphologically identified as Ixodes texanus and Ixodes soricis. For Ixodes texanus, this genetic divergence was further supported by subtle morphological variation which further strengthens the cryptic species hypothesis. When evaluating species that have not been previously barcoded, cryptic species are often revealed (Clarke et al. 2006; Hebert et al. 2004; Smith 2008; Witt et al. 2006).

The revelation of cryptic diversity is of particular relevance for numerous ixodid tick species. In a study comparing 400 successfully barcoded ixoded ticks by Zhang and Zhang (2014), 12 species of ticks were found to exhibit exceptionally high intraspecific divergences out of a total 70 species across 14 genera. The authors suggest that this could represent the presence of cryptic diversity, but could also be a result of inaccurate identification (possibly due to mitochondrial introgression and hybridization). In a study of 130 immature tick sequences compared to an assembled 96 sequence adult tick barcode library, Miller et al. (2014) found the presence of possible cryptic diversity in Haemaphysalis juxtakochi and Amblyomma ovale. Miller et al. (2014) found both species split into two barcode clusters, and a BIN analysis showed each species was experiencing a SPLIT pattern (see Ratnasingham and Hebert, 2013) of BIN organization, similarly to what was observed within I. texanus and I. soricis in the current study. These studies, in addition to the current study, highlight the complexity of tick specimen identification and the need for taxonomic revision of potentially cryptic tick species. 
A limitation present in this study and in all genetic methods for identifying species is that sequence generation rates can be less than ideal if the specimens are aged or not properly preserved (Watts et al. 2007; King and Porter, 2004). The authors suspect that DNA barcodes were only generated for 96 out of 166 specimens in this study due to DNA degradation caused by specimens age (up to 18 years), and the majority of the specimens being improperly stored in isopropyl alcohol as opposed to standard $95 \%$ ethanol.

The first tick-focused DNA barcode study was published by Lv et al. (2014a). Lv et al. (2014a) argue for the use of a three-gene DNA barcode system, including CO1, 16S, and 18S, for ticks as opposed to using COI alone. The reasoning behind using three-gene systems is not because it more accurately provides species delineations, but rather that there is not a sufficient COI sequence library on BOLD or GenBank to provide species-level matches for some tick species. While Lv et al. provide a novel solution to the lack of reference sequence library, this solution creates additional costs and efforts for limited added benefit and primarily relies on GenBank data that lacks the data integrity that BOLD offers. BOLD requires that all sequences must be associated with the following criteria in order to be considered a "barcodecompliant" sequence: 1) species name, 2) voucher information (including catalogue number and institution storing), 3) collection information (collector, collection date, and location with GPS coordinates), 4) identifier of the specimen, 5) for animals a COI sequence of at least $500 \mathrm{bp}, 6$ ) polymerase chain reaction (PCR) primers used to generate the amplicon, 7) raw trace files (Ratnasingham et al. 2007). These community standards increase the level of transparency, reproducibility, and taxonomic confidence of DNA barcoding (Ondrejicka et al. 2014) and even allow scientists to request voucher specimens when there are discrepancies between specimen identifications. In a follow up study, Lv et al. (2014b) found that there was no significant difference in the efficacy of 12S, 16S, ITS2, or COI for use in the identification of tick specimens; however, they found the use of COI ideal due to the utility and large COI sequence collection of BOLD. 
In addition to increasing data integrity, BOLD offers new prospects for linking tick specimen identification with the identification of the tick`s host. In 2012, a study by Gariepy et al. validated a method to use DNA barcoding to identify the host species through tick bloodmeals. When both tick and host identifications are linked on BOLD, this becomes a powerful tool for ecologists.

\section{B. burgdorferi Testing}

While midgut or whole specimen testing is the norm when screening for B. burgdorferi, systemic testing was used in this study for three reasons (Persing et al. 1990). 1) A leg DNA extract, which was initially used for barcoding, was easily screened for B. burgdorferi without further harming the morphological voucher specimen. 2) vVery few studies have examined the rate of systemic infections, especially in less common vector ticks, such as I. muris. It is also known that systemic infection varies by species (Crippa et al. 2002). 3) No known studies have attempted to test tick exoskeletons for the presence of $B$. burgdorferi.

It is important to note that performing a systemic test for B. burgdorferi does not rule out the possibility that a particular tick harbours a midgut infection. Therefore, additional Lyme-competent specimens included in this study may be infected in their midgut, but not exhibiting a systemic infection, suggesting that our results represent a conservative estimate of infection rate. While individuals from 7 Lymecompetent species were tested, only I. scapularis ticks were positive in this study. Notably, this study is the first to detect $B$. burgdorferi from an exoskeleton. This finding may provide a method of investigating the infection status of morphologically important voucher specimens, without sacrificing the specimen or distorting any anatomical part of the newly-molted tick. Further research should investigate the frequency of exoskeleton infection compared to midgut infection. As well, future studies should verify that the same abdominal-derived extract might be used for both host identification and infection status determination.

The ability to both identify specimens to species level and to screen for important pathogens from the same whole genomic extract allows for expanded applications of DNA barcoding for public health 
monitoring. Real-time quantitative PCR (qPCR) has been shown to be a fast and highly accurate technique for use in the detection and quantification of bacterial pathogens present in municipal water sources to screen for potential risks of pathogen exposure (Shannon et al. 2007). A duplexed qPCR assay designed to be able to simultaneously identify if a specimen is an important Lyme-competent vector with species-specific accuracy (for example, I. scapularis) and identify the presence of B. burgdorferi within a specimen (for example, by detecting the $O s p A$ gene) within a single DNA extract could allow for the rapid and accurate screening of potential tick-related health risks. The ability to identify host identities as well as information about pathogen presence is valuable, as it can allow for improved risk assessments. Being able to determine if you have the right host species as well as being able to determine if the particular specimen poses a risk of pathogen transmission to the public simultaneously can allow for more rapid and more informed risk-prevention decisions. Further study into the suitability of assays like realtime qPCR for the simultaneous identification of pathogen host and pathogen presence for the screening of Lyme-competent ticks is recommended.

\section{Conclusion}

This study significantly increases the barcode reference sequence library for Canadian ticks. It also demonstrates the presence of a "barcode gap," with the distance between nearest neighbour species being $8 \mathrm{x}$ greater than the mean maximum intraspecific variation, suggesting that barcodes are highly effective for discriminating tick species. Importantly, it extends our ability to confidently identify immature stages, damaged specimens, and fragmentary remains that are often encountered in a clinical setting. This study also reveals two putative cryptic species based on genetic divergence and BIN analysis originally identified as Ixodes texanus and Ixodes soricis. Furthermore, a PCR-based test determined that $18 \%$ of Lyme-competent ticks in this study were positive for systemic B. burgdorferi infection. We provide the first-ever report of a B. burgdorferi positive exoskeleton from a molted tick. Future work should focus on increasing coverage for these taxa and ideally involve comparisons with type specimens as part of a comprehensive taxonomic revision, as well as further exploring the potential for assays to be designed 
that allow for simultaneous specimen detection and B. burgdorferi infection detection. Based on the results of the 26 species of ixodid ticks examined, DNA barcoding provided a rapid, accurate, and costeffective DNA-based method to enhance the identification of tick specimens.

\section{Acknowledgments}

We sincerely thank John D. Scott for initiating this study and supplying ixodid tick specimens for analysis. We further thank John and Kitt Scott for their thoughtful comments and aid in preparation of the manuscript. We thank Natasha Serrao and Andrew Frewin for their expertise and assistance with lab work, and Jeff Gross for support with DNA sequencing. In addition, we are grateful to Lance A. Durden for helping to identify extralimital ixodid ticks. We thank Chris Weland for further suggestions on additional PCR primer combinations for acquiring barcode sequences from difficult specimens. We thank the BOLD Informatics team for efficient data support and the collections team at the Biodiversity Institute of Ontario for accessioning the morphological voucher specimens associated with this study. We acknowledge the Government of Canada for support for the International Barcode of Life (iBOL.org) project with funding provided by Genome Canada through the Ontario Genomics Institute, and the Province of Ontario for support from the Emergency Management Program at OMAFRA. 


\section{References:}

Anderson, J.M., Ammerman, N.C., and Norris, D.E. 2004. Molecular differentiation of metastriate tick immatures. Vector Borne Zoonotic Dis. 4: 332-341.

Ball, S.L., Hebert, P.D.N., S.K. Burian and Webb, J.M. 2005. Biological identifications of mayflies (Ephemeroptera) using DNA barcodes, J. North. Am. Benthol. Soc. 24: 508-524.

Barber-James, H.M., Gattolliat J.L., Sartori M., \& Hubbard M.D. 2008. Global diversity of mayflies (Ephemeroptera, Insecta) in freshwater. Hydrobiologia. 595: 339-350.

Barrett, R.D.H. and Hebert, P.D.N. 2005. Identifying spiders through DNA barcodes. Can. J. Zool. 83: $481-491$.

Besansky, N.J., Severson, D.W. and Ferdig, M.T. 2003. DNA barcoding of parasites and invertebrates disease vectors: what you don't know can hurt you. Trends Parasitol. 19: 545-546.

Burgdorfer, W., Barbour A. G., Hayes, S.F., Benach, J.L., Grunwaldt, E., and Davis, J.P. 1982. Lyme disease—a tick-borne spirochetosis?, Science. 216: 1317-1319.

Canadian Lyme Disease Foundation, 2016. Lyme Basics: Tick ID [online]. Available from http://canlyme.com/lyme-basics/tick-id/ [accessed 12 May 2016].

Clarke, E.L., Lim, B.K., Engstrom, M.D., Eger, J.L. and Hebert, P.D.N. 2006. DNA barcoding of neotropical bats: species identification and discovery within Guyana. Mol. Ecol. Notes. 7: 184-190.

Crippa, M., Rais, O., and Gern, L. 2002. Investigations on the mode and dynamics of transmission and infectivity of Borrelia burgdorferi sensu stricto and Borrelia afzelii in Ixodes ricinus ticks. Vector Borne Zoonotic Dis. 1: 3-9.

Cywinska, A., Hunter, F.F., and Hebert, P.D.N. 2006. Identifying Canadian mosquito species through DNA barcodes. Med. Vet. Entomol. 4: 413-424. 
Dolan, M.C., Lacombe, E. H. \& Piesman, J. 2000. Vector competence of Ixodes muris (Acari: Ixodidae) for Borrelia burgdorferi. J. Med. Entomol. 37: 766-768.

Durden, L.A. and Keirans, J.E. 1996. Nymphs of the genus Ixodes (Acari: Ixodidae) of the United States: taxonomy, identification key, distribution, hosts, and medical/veterinary importance, Thomas Say Publications in Entomology, Entomological Society of America.

Eisen, L., and Lane, R.S. 1996. Vectors of Borrelia burgdorferi sensu lato. In: Gray, J., Kah, O., Lane, R.S., and Stanek, G. (Eds.), Lyme borreliosis: Biology, epidemiology and control, CABI Publishing.

Folmer, O., Black, M., Hoeh, W., Lutz, R., and Vrijenhoek, R. 1994. DNA primers for amplification of mitochondrial cytochrome c oxidase subunit I from diverse metazoan invertebrates. Mol. Marine Biol. Biotechnol. 3: 294-299.

Gariepy, T.D., Lindsay, R., Ogden, N., and Gregory, T.R. 2012. Identifying the last supper: utility of the DNA barcode library for bloodmeal identification in ticks. Mol. Ecol. Res. 12: 646-652.

Gregson, JD. 1956. The Ixodoidea of Canada. In Canada Department of Agriculture Science Service, Entomology Division Publication. 930: 1-9.

Guglielmone, A., Robbins, R.G., Apanaskevich, D.A., Petney, T.N., Estrada-Pena, A, Horak, I.G., et al. 2010. The Argasidae, Ixodidae and Nuttalliellidae of the world: a list of valid species names. Zootaxa. 2528: $1-28$.

Hajibabaei, M., Janzen, D.H., Burns, J.M., Hallwachs, W., and Hebert, P.D.N. 2006. DNA barcodes distinguish species of tropical Lepidoptera. Proc. Natl. Acd. Sci. U.S.A. 103: 968-971.

Hebert, P.D.N., Cywinska, A., Ball, S., and DeWaard, J.R. 2003a. Biological identifications through DNA barcodes. Proc. R. Soc. Lond., B, Biol. Sci. 270: 313-321. 
Hebert, P.D.N., Ratnasingham, S., and DeWaard, J.R. 2003b. Barcoding animal life: CO1 divergences among closely allied species. Proc. R. Soc. Lond., B, Biol. Sci. 270: 596-599.

Hebert P.D.N., Penton E.H., Burns J.M., Janzen D.H., and Hallwachs W. 2004. Ten species in one: DNA barcoding reveals cryptic species in the neotropical skipper butterfly Astraptes fulgerator. Proc. Natl. Acad. Sci. U.S.A. 101: 14812-14817.

Keirans, J.E and Clifford, C.M. 1978. The genus Ixodes in the United States; a scanning electron microscope study and key to the adults. J. Med. Entomol. 15: Supplement 2.

Kimura, M. 1980. A simple method for estimating evolutionary rates of base substitutions through comparative studies of nucleotide sequences. J. Mol. Evol. 16: 111-120.

King, J.R. and Porter, S.D. 2004. Recommendations on the use of alcohols for preservation of ant specimens (Hymenoptera, Formicidae). Insect. Soc. 51: 197-20.

Lv, J., Wu, S., Zhang, Y., Zhang, T., Feng, C., Jia, G., et al. 2014a. Development of a DNA barcoding system for the Ixodida (Acari: Ixodida). Mitchondrial DNA. 25: 142-149.

Lv, J., Wu, S., Zhang, Y., Chen, Y., Feng, C., Yuan, X., et al. 2014b. Assessment of four DNA fragments (COI, 16S rDNA, ITS2, 12S rDNA) for species identification of the Ixodida (Acari: Ixodida). Parasit. Vectors. 7: 1-11.

Mans, B.J., de Klerk, D., Pienaar R., and Latif A.A. 2011. Nuttalliella namaqua: A Living Fossil and Closest Relative to the Ancestral Tick Lineage: Implications for the Evolution of Blood-Feeding in Ticks,. PLoS ONE. 6: e23675. doi:10.1371/journal.pone.0023675

Matuschka, F.R., Ohlenbusch, A., Eiffert, H., Richter, D., and Spielman A. 1996. Characteristics of Lyme disease spirochetes in archived European ticks. J. Infect. Dis. 174: 424-427. 
Miller, M.J., Esser, H.J., Loaiza, J.R., Herre, E.A., Aguilar, C., Quintero, D., et al. 2014. Molecular insights into Neotropical bird-tick ecological associations and the role of birds in tick-borne disease ecology. arXiv (preprint). arXiv: 1411.6686.

Ondrejicka, D.A., Locke, S.A., Morey, K., Borisenko, A.V., and Hanner, R.H. 2014. Status and prospects of DNA barcoding in medically important parasites and vectors. Trends Parasitol. 30: 582-591.

Ogedengbe, J. D., Hanner, R. H., and Barta, J. R. 2011. DNA barcoding identifies Eimeria species and contributes to the phylogenetics of coccidian parasites (Eimeriorina, Apicomplexa, Alveolata). Int. J. Parasitol. 41: 843-850.

Penny, D. and Phillips, M. J. 2004. The rise of birds and mammals: are microevolutionary processes sufficient for evolution? Trends. Ecol. Evol. 19: 516-522.

Persing, D.H., Telford, S.R., Spielman, A., and Barthold, S. 1990. Detection of Borrelia burgdorferi infection in Ixodes dammini ticks with polymerase chain reaction. J. Clin. Microbiol. 28: 566-572.

Ratnasingham, S., and Hebert, P.D.N. 2007. BOLD: The Barcode of Life Data System. Mol. Ecol. Notes. 7: $355-364$.

Ratnasingham, S. and Hebert, P.D.N. 2013. A DNA-based registry for all animal species: the barcode index number (BIN) system. PLoS One. 8: e66213.

Nei M. and Kumar S. 2000. Molecular Evolution and Phylogenetics, Oxford University Press, New York.

Shannon, K.E., Lee, D.Y., Trevors, J.T., and Beaudette, L.A. 2007. Application of real-time quantitative PCR for the detection of selected bacterial pathogens during municipal wastewater treatment. Sci. Total Environ. 382: 121-129. 
Simon, C., Frati, F., Beckenbach, A., Crespi, B., Liu, H., and Flook, P. 1994. Evolution, weighting, and phylogenetic utility of mitochondrial gene-sequences and a compilation of conserved polymerase chainreaction primers. Ann. Entomol. Soc. Am. 87: 651-701.

Smith, A.M., Fisher, B.L., and Hebert, P.D.N. 2005. DNA barcoding for effective biodiversity assessment of a hyper diverse arthropod group: the ants of Madagascar. Philos. Trans. R. Soc. Lond., B, Biol. Sci. 360: 1825-1834.

Smith, A.M., Rodriguez, J.J., Whitfield, J.B., Deans, A.R., Janzen, D.H., Hallwachs, W.H., et al., 2008. Extreme diversity of tropical parasitoid wasps exposed by iterative integration of natural history, DNA barcoding, morphology, and collections. Proc. Natl. Acad. Sci. U.S.A. 105: 12359-12364.

Tamura, K., Peterson, D., Peterson, N., Stecher, G., Nei, M., and Kumar, S. 2011. MEGA5: molecular evolutionary genetics analysis using likelihood, distance, and parsimony methods. Mol. Biol. Evol. 28: 2731-2739.

Watts P.C., Thompson D.J., Allen K.A., and Kemp S.J. 2007. How useful is DNA extracted from the legs of archived insects for microsatellite-based population genetic analyses? J. Insect. Conserv. 11: 195-198. Ward, R.D., Zemlak, T.S., Innes, B.H., Last, P.R., and Hebert, P.D.N. 2005. DNA barcoding Australia's fish species. Philos. Trans. R. Soc. Lond., B, Biol. Sci. 360: 1847-1857.

Webster, B. L., Culverwell, C. L., Khamis, I. S., Mohammed, K. A., Rollinson, D., and Stothard, J. R. 2013. DNA barcoding of Schistosoma haematobium on Zanzibar reveals substantial genetic diversity and two major phylogenetic groups. Acta. Trop. 128: 206-217.

Witt, J.D., Threloff, D.L., and Hebert, P.D.N. 2006. DNA barcoding reveals extraordinary cryptic diversity in an amphipod genus: implications for desert spring conservation. Mol. Ecol. 15: 3073-3082. 
Zhang, R. and Zhang, B. 2014. Prospects of using DNA barcoding for species identification and evaluation of the accuracy of sequence databases for ticks (Acari: Ixodida). Ticks Tick. Borne Dis. 5: $352-358$. 


\section{Tables}

Table 1. Primer sequences used in PCR for DNA barcoding.

\begin{tabular}{|c|c|c|c|}
\hline Order & Primer & Sequence & Reference \\
\hline \multirow[b]{2}{*}{1} & LCO1490 & 5'-ggtcaacaaatcataaagatattgg-3' & \multirow[t]{2}{*}{ Folmer et al. 1994} \\
\hline & HCO2198 & $\begin{array}{l}\text { 5'-taaacttcagggtgaccaaaaaatca- } \\
3 \text {, }\end{array}$ & \\
\hline \multirow{2}{*}{2} & LepF1 & 5'-attcaaccaatcataaagatat-3' & \multirow[t]{2}{*}{ Hebert et al. 2004} \\
\hline & LepR1 & 5'-taaacttctggatgtccaaaa- $3^{\prime}$ & \\
\hline \multirow{4}{*}{3} & LCO1490 & 5'-ggtcaacaaatcataaagatattgg-3' & \multirow[t]{4}{*}{ Folmer et al. 1994 and Hebert et al. 2004} \\
\hline & $\mathrm{HCO} 2198$ & $\begin{array}{l}\text { 5'-taaacttcagggtgaccaaaaaatca- } \\
3 \text {, }\end{array}$ & \\
\hline & LepF1 & 5'-attcaaccaatcataaagatat-3' & \\
\hline & LepR1 & 5'-taaacttctggatgtccaaaa- 3' & \\
\hline \multirow{4}{*}{4} & LCO1490 & 5'-ggtcaacaaatcataaagatattgg-3' & \multirow{4}{*}{$\begin{array}{l}\text { Folmer et al. 1994, Hebert et al. 2004, Simon } \\
\text { et al. 1994, and Smith et al. } 2005\end{array}$} \\
\hline & LepF1 & 5'-attcaaccaatcataaagatattgg-3' & \\
\hline & RonIIdeg_R & $\begin{array}{l}5 '- \\
\text { ggrggrtarayagttcatccwgtwcc-3', }\end{array}$ & \\
\hline & AMR1deg_R & $\begin{array}{l}5 \text { '-cawccwgtwcckrmnccwkcat- } \\
3 \text {, }\end{array}$ & \\
\hline \multirow{3}{*}{5} & MLepF1 & 5'-gctttcccacgaataaataata-3' & \multirow{3}{*}{$\begin{array}{l}\text { Hajibabaei et al 2006, Folmer et al 1994, and } \\
\text { Hebert et al. } 2004\end{array}$} \\
\hline & $\mathrm{HCO} 2198$ & $\begin{array}{l}5 \text { '-taaacttcagggtgaccaaaaaatca- } \\
3 \text {, }\end{array}$ & \\
\hline & LepR1 & 5'-taaacttctggatgtccaaaa- 3' & \\
\hline
\end{tabular}


Table 2. OspA primer sequences used to detect B. burgdorferi

\begin{tabular}{llll}
\hline Outer/ Inner & Position & Sequence & Reference \\
\hline Outer & $169-194$ & GGTCTAATATTAGCCTTAATAGGCATG & Matuschka et al. 1996 \\
\hline Outer & $665-643$ & TCAGCAGCTAGAGTTCCTTCAAG & Matuschka et al. 1996 \\
\hline Inner & $191-214$ & CATGTAAGCAAAATGTTAGCAGCC & Matuschka et al. 1996 \\
\hline Inner & $589-568$ & CTGTGTATTCAAGTCTGGTTCC & Matuschka et al. 1996 \\
\hline
\end{tabular}


Table 3. Collection sites and sources of 22 genomic DNA samples tested for infection by B. burgdorgeri

\begin{tabular}{|c|c|c|c|}
\hline Tick species & Part of tick tested & Location collected & Presence of $B$. burgdorferi? \\
\hline Ixodes scapularis & Leg & Turkey Point, ON & Yes \\
\hline I. scapularis & Exoskeleton & Toronto, ON & Yes \\
\hline I. scapularis & Exoskeleton & Sibley Peninsula, ON & Yes \\
\hline I. scapularis & Exoskeleton & Sibley Peninsula, ON & Yes \\
\hline I. affinis & Leg & Georgia, USA & No \\
\hline I. affinis & Leg & United States & No \\
\hline I. dentatus & Leg & Long Point, ON & No \\
\hline I. dentatus & Leg & Long Point, ON & No \\
\hline I. muris & Leg & New Brunswick, Canada & No \\
\hline I. muris & Leg & Nova Scotia, Canada & No \\
\hline I. muris & Leg & McGill Bird Observatory, QB & No \\
\hline I. baergi & Leg & Elora, $\mathrm{ON}$ & No \\
\hline I. pacificus & Leg & United States & No \\
\hline I. pacificus & Leg & Victoria, BC & No \\
\hline I. pacificus & Leg & California, USA & No \\
\hline I. spinipalpus & Leg & Cypress Hills, ON & No \\
\hline I. spinipalpus & Leg & Ontario, Canada & No \\
\hline I. spinipalpus & Leg & Vancouver Island, BC & No \\
\hline I. scapularis & Exoskeleton & 28 & No \\
\hline I. scapularis & Exoskeleton & $\mathrm{N} / \mathrm{A}$ & No \\
\hline I. scapularis & Leg & Canada & No \\
\hline I. scapularis & Leg & Canada & No \\
\hline
\end{tabular}


Table 4. Summary of divergences observed within genera produced by the barcode gap analysis on BOLD.

\begin{tabular}{cccccc}
\hline Genus & $\begin{array}{c}\text { Number } \\
\text { of } \\
\text { Species }\end{array}$ & $\begin{array}{c}\text { Mean } \\
\text { Maximum } \\
\text { Intraspecific } \\
\text { Divergence (\%) }\end{array}$ & $\begin{array}{c}\text { Range of } \\
\text { Maximum } \\
\text { Intraspecific } \\
\text { Divergences } \\
(\text { Min\% - Max\%) }\end{array}$ & $\begin{array}{c}\text { Mean } \\
\text { Distance to } \\
\text { Nearest } \\
\text { Neighbour } \\
(\%)\end{array}$ & $\begin{array}{c}\text { Range of } \\
\text { Mean } \\
\text { Distances to } \\
\text { Nearest } \\
\text { Neighbour } \\
\text { (Min\% - } \\
\text { Max\%) }\end{array}$ \\
\hline Amblyomma & 6 & 0.77 & $0.00-2.57$ & 16.87 & $16.32-17.17$ \\
\hline Dermacentor & 2 & 2.51 & $1.73-3.29$ & 10.80 & $10.80-10.80$ \\
\hline Haemaphysalis & 1 & 0.46 & - & 16.18 & - \\
\hline Ixodes & 16 & 1.87 & $0.00-14.50$ & 11.03 & $3.60-17.94$ \\
\hline Rhipicephalus & 1 & 0.49 & - & 16.18 & - \\
\hline
\end{tabular}




\section{Figure Captions}

Figure 1. Collection sites for ixodid tick specimens acquired between 1993 and 2012 from Canada, the United States, Mexico, and Costa Rica. Map generated using SimpleMappr.

Figure 2. Collection sites for ixodid tick specimens acquired between 1993 and 2012 from Ontario and Quebec. Map generated using SimpleMappr.

Figure 3. Neighbour joining tree analysis of 96 tick sequences from 5 genera, including 26 different species. Analysis was conducted using a Kimura 2 Parameter (K2P) distance model with branch lengths drawn to scale. The terminal node of each haplogroup was collapsed, with the height of the terminal node proportional to the number of sequences and depth proportional to sequence divergence within a haplogroup. Analysis shows ixodid tick species distinguish into distinct haplogroups or "barcode clusters", with the exception of I. texanus (clusters A and B), and I. soricis (clusters C and D) with each distinguishing into two haplogroups each (indicated as Cluster A-D). Evolutionary analysis and tree construction were performed using MEGA 6.06.

Figure 4. Barcode gap analysis comparing the maximum intraspecific distances with the nearest neighbor distances (a metric of interspecific distance) using a Kimura 2 Parameter distance model and a MUSCLE alignment. All non-singleton species of ixodid ticks with DNA barcodes of $\geq 500 \mathrm{bp}$ length successfully generated in this study were included in the analysis. The majority of species showed low maximum intraspecific distances and large nearest neighbor distances (solid black dots), indicating the presence of a "barcode gap". Two notable outliers were observed: 1) Ixodes soricis (solid white dot) was found to have a greater nearest neighbor distance than maximum intraspecific distance, and 2) I. texanus (white dot with cross) was found to have much larger divergences than all other included species, with a 9.1x greater maximum intraspecific distance than the mean maximum intraspecific divergence observed. 


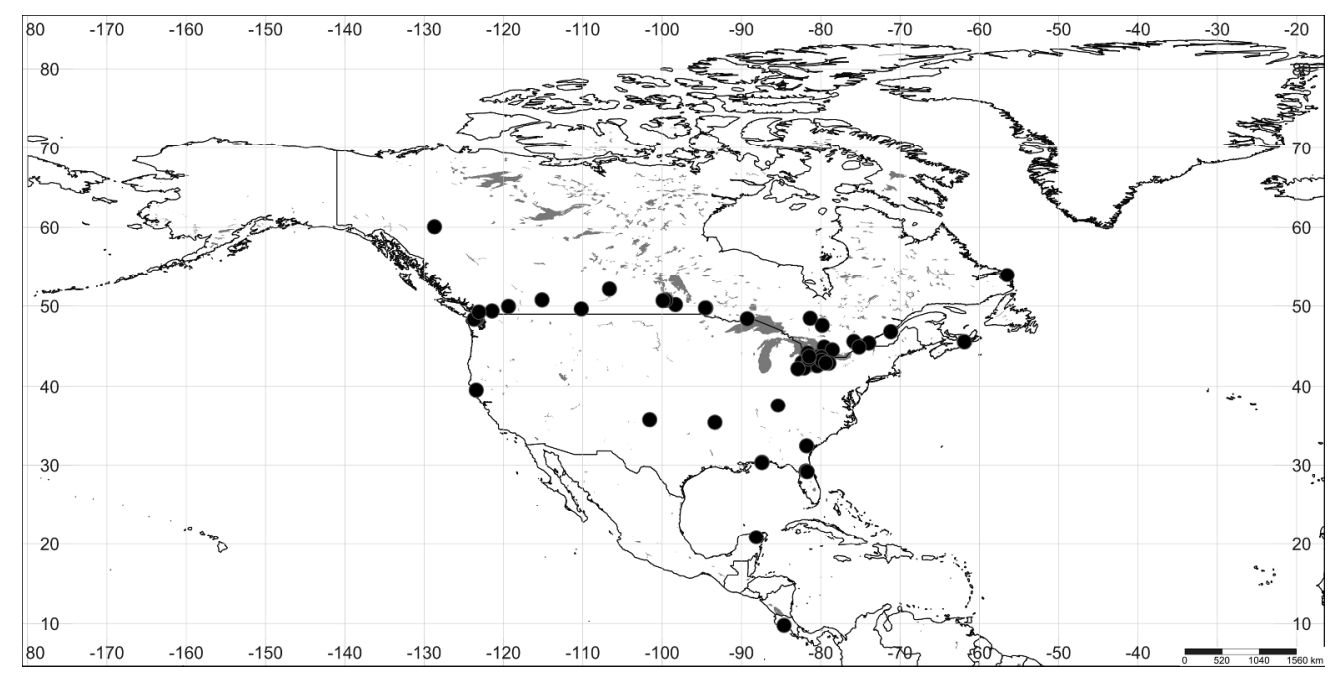

Figure 1

$228 \times 114 \mathrm{~mm}(300 \times 300 \mathrm{DPI})$ 
Page 29 of 46

Genome

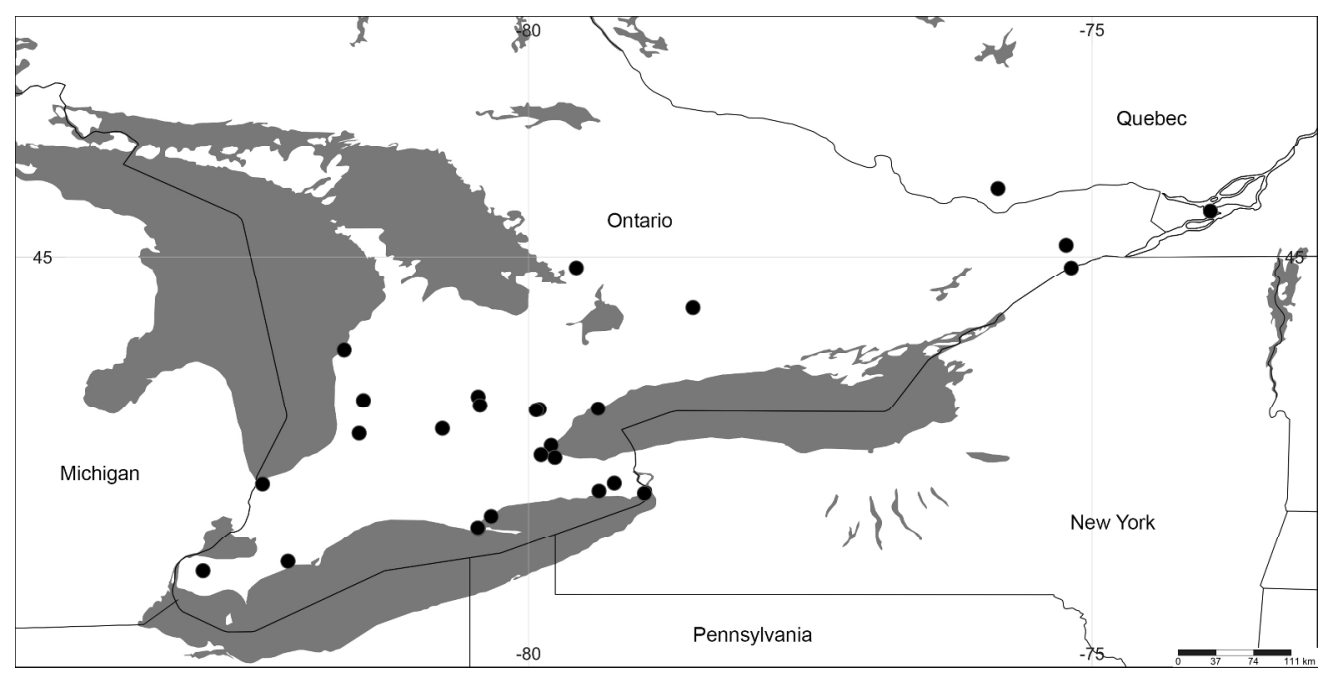

Figure 2

$228 \times 114 \mathrm{~mm}(300 \times 300$ DPI $)$

https://mc06.manuscriptcentral.com/genome-pubs 


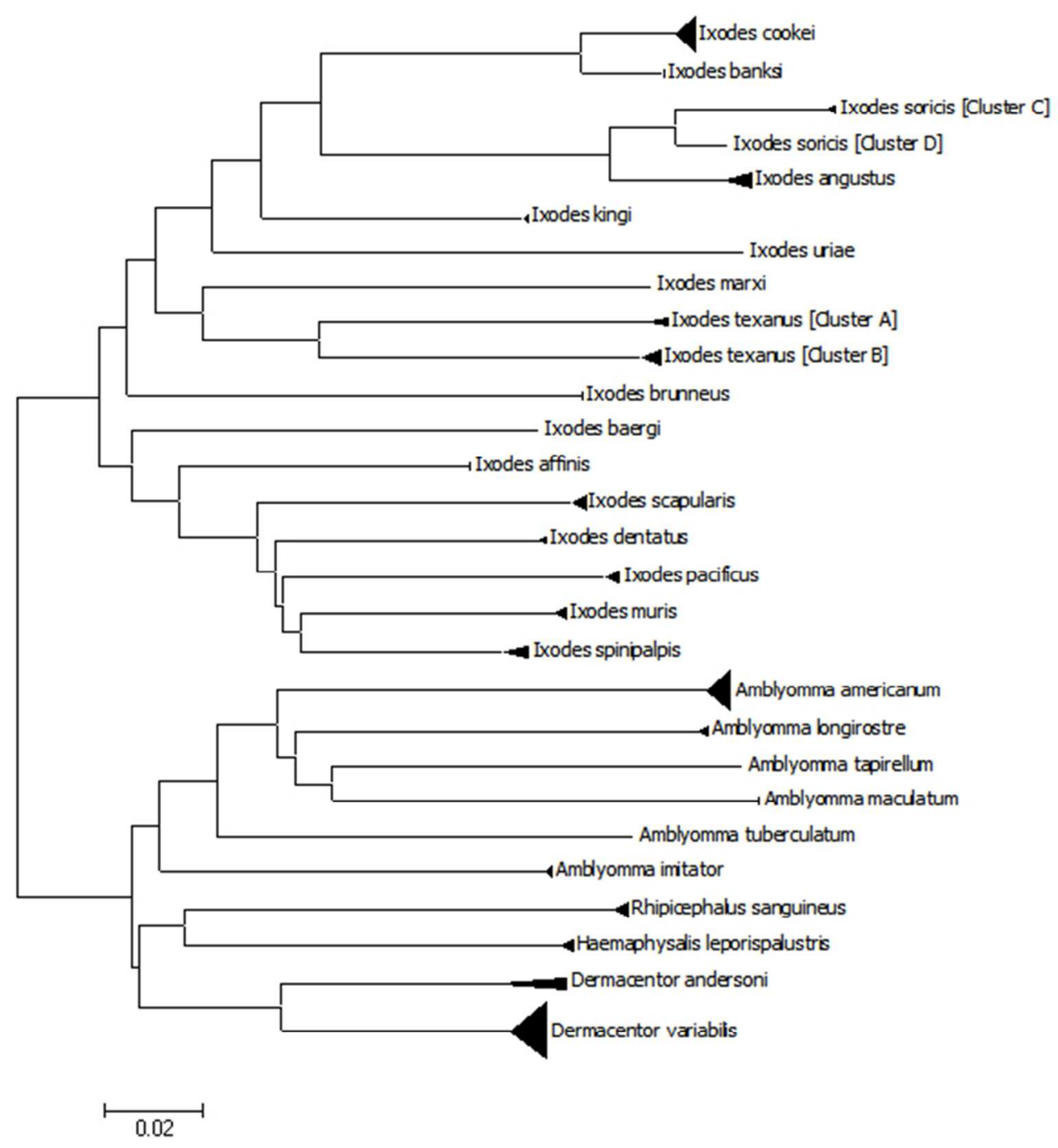

Figure 3

$50 \times 53 \mathrm{~mm}(300 \times 300$ DPI $)$ 


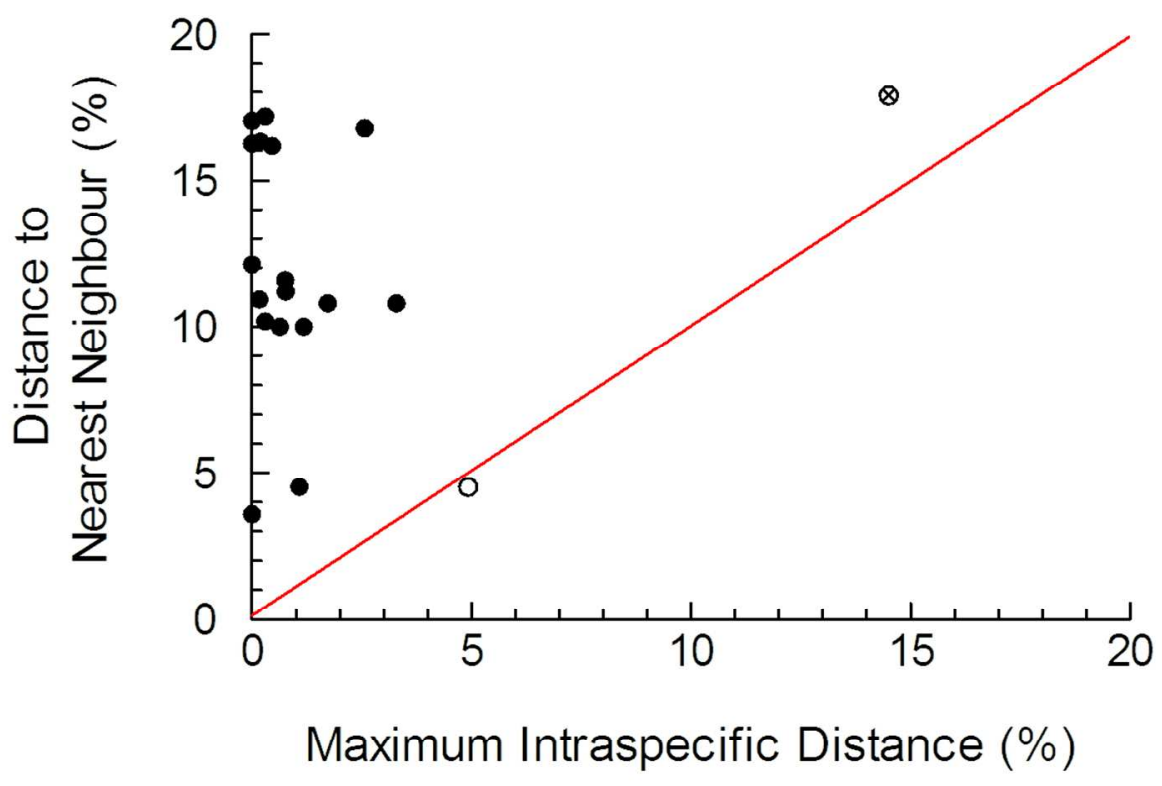

Figure 4

$113 \times 79 \mathrm{~mm}(300 \times 300$ DPI $)$ 
Supplemental Data 1. Specimen Information Table

\begin{tabular}{|c|c|c|c|}
\hline Sample ID & BOLD Process ID & $\begin{array}{l}\text { GenBank Accession } \\
\text { Number }\end{array}$ & Species \\
\hline DO-006 & TODO001-11 & KX360354 & $\begin{array}{l}\text { Haemaphysalis } \\
\text { leporispalustris }\end{array}$ \\
\hline DO-007 & TODO002-11 & KX360417 & Ixodes cookei \\
\hline DO-023 & TODO003-11 & KX360416 & Ixodes scapularis \\
\hline DO-028 & TODO004-11 & KX360382 & Ixodes scapularis \\
\hline DO-030 & TODO005-11 & KX360339 & Dermacentor variabilis \\
\hline DO-035 & TODO006-11 & KX360407 & Amblyomma americanum \\
\hline DO-039 & TODO007-11 & KX360331 & Ixodes scapularis \\
\hline DO-042 & TODO008-11 & KX360377 & Ixodes scapularis \\
\hline DO-048 & TODO009-11 & KX360340 & Ixodes cookei \\
\hline DO-050 & TODO040-11 & KX360412 & Ixodes texanus \\
\hline DO-056 & TODO043-11 & KX360399 & Ixodes muris \\
\hline DO-059 & TODO044-11 & KX360379 & Amblyomma maculatum \\
\hline DO-062 & TODO046-11 & KX360372 & Ixodes muris \\
\hline DO-063 & TODO047-11 & KX360390 & Ixodes texanus \\
\hline DO-071 & TODO067-11 & KX360342 & Ixodes texanus \\
\hline DO-074 & TODO070-11 & KX360385 & Ixodes spinipalpis \\
\hline DO-075 & TODO108-11 & KX360366 & Ixodes marxi \\
\hline DO-081 & TODO109-11 & KX360408 & Ixodes pacificus \\
\hline DO-085 & TODO105-11 & KX360343 & Ixodes pacificus \\
\hline DO-089 & TODO083-11 & KX360328 & Ixodes affinis \\
\hline
\end{tabular}




\begin{tabular}{|c|c|c|c|}
\hline DO-091 & TODO085-11 & KX360360 & Ixodes kingi \\
\hline DO-092 & TODO086-11 & KX360380 & Ixodes kingi \\
\hline DO-093 & TODO087-11 & KX360400 & Ixodes brunneus \\
\hline DO-095 & TODO089-11 & KX360422 & Ixodes affinis \\
\hline DO-099 & TODO091-11 & KX360351 & Amblyomma imitator \\
\hline DO-100 & TODO092-11 & KX360341 & Amblyomma imitator \\
\hline DO-101 & TODO093-11 & KX360364 & Ixodes brunneus \\
\hline DO-103 & TODO095-11 & KX360396 & Ixodes muris \\
\hline DO-104 & TODO096-11 & KX360344 & Amblyomma maculatum \\
\hline DO-105 & TODO097-11 & KX360356 & Amblyomma longirostre \\
\hline DO-106 & TODO098-11 & KX360336 & Rhipicephalus sanguineus \\
\hline DO-107 & TODO099-11 & KX360329 & Amblyomma longirostre \\
\hline DO-109 & TODO107-11 & KX360371 & Amblyomma tuberculatum \\
\hline DO-111 & TODO100-11 & KX360363 & Amblyomma longirostre \\
\hline DO-112 & TODO101-11 & KX360370 & Amblyomma tapirellum \\
\hline DO-117 & TODO106-11 & KX360376 & Amblyomma imitator \\
\hline DO-118 & TODO103-11 & KX360388 & Ixodes baergi \\
\hline DO-123 & TODO104-11 & KX360373 & Ixodes soricis \\
\hline DO-145 & TODO142-12 & KX360402 & Ixodes texanus \\
\hline DO-147 & TODO140-12 & KX360368 & Ixodes banksi \\
\hline DO-149 & TODO144-12 & KX360383 & Ixodes texanus \\
\hline DO-151 & TODO143-12 & KX360404 & Ixodes texanus \\
\hline
\end{tabular}




\begin{tabular}{|c|c|c|c|}
\hline DO-152 & TODO145-12 & KX360421 & Ixodes pacificus \\
\hline DO-153 & TODO146-12 & KX360375 & Ixodes spinipalpis \\
\hline DO-159 & TODO147-12 & KX360374 & Ixodes dentatus \\
\hline DO-160 & TODO148-12 & KX360409 & Ixodes dentatus \\
\hline DO-161 & TODO141-12 & KX360369 & Ixodes banksi \\
\hline DO-168 & TODO149-12 & KX360381 & Dermacentor andersoni \\
\hline DO-169 & TODO150-12 & KX360395 & Dermacentor andersoni \\
\hline DO-170 & TODO151-12 & KX360398 & Dermacentor andersoni \\
\hline DO-200 & TODO011-11 & KX360393 & Ixodes cookei \\
\hline DO-201 & TODO012-11 & KX360361 & Dermacentor variabilis \\
\hline DO-203 & TODO013-11 & KX360353 & Ixodes cookei \\
\hline DO-205 & TODO014-11 & KX360387 & Dermacentor variabilis \\
\hline DO-206 & TODO015-11 & KX360384 & Dermacentor variabilis \\
\hline DO-207 & TODO016-11 & KX360391 & $\begin{array}{l}\text { Haemaphysalis } \\
\text { leporispalustris }\end{array}$ \\
\hline DO-208 & TODO017-11 & KX360359 & Ixodes cookei \\
\hline DO-211 & TODO019-11 & KX360337 & $\begin{array}{l}\text { Haemaphysalis } \\
\text { leporispalustris }\end{array}$ \\
\hline DO-212 & TODO020-11 & KX360346 & Dermacentor variabilis \\
\hline DO-213 & TODO021-11 & KX360365 & Ixodes cookei \\
\hline DO-218 & TODO025-11 & KX360358 & Ixodes cookei \\
\hline DO-219 & TODO026-11 & KX360378 & Ixodes cookei \\
\hline DO-221 & TODO028-11 & KX360333 & Dermacentor variabilis \\
\hline DO-222 & TODO029-11 & KX360405 & $\begin{array}{l}\text { Haemaphysalis } \\
\text { leporispalustris }\end{array}$ \\
\hline
\end{tabular}




\begin{tabular}{|c|c|c|c|}
\hline DO-223 & TODO030-11 & KX360330 & Ixodes cookei \\
\hline DO-225 & TODO032-11 & KX360413 & Ixodes cookei \\
\hline DO-226 & TODO033-11 & KX360415 & Dermacentor variabilis \\
\hline DO-230 & TODO036-11 & KX360332 & Dermacentor variabilis \\
\hline DO-306 & TODO055-11 & KX360338 & Rhipicephalus sanguineus \\
\hline DO-309 & TODO056-11 & KX360403 & Rhipicephalus sanguineus \\
\hline DO-311 & TODO057-11 & KX360367 & Rhipicephalus sanguineus \\
\hline 10AVB-PAR0064 & CSBMP064-10 & HМ398837 & Ixodes soricis \\
\hline 10AVB-PAR0065 & CSBMP065-10 & KX360410 & Ixodes soricis \\
\hline 10AVB-PAR0191 & TGBT001-10 & KX360420 & Amblyomma americanum \\
\hline 10AVB-PAR0192 & TGBT002-10 & KX360347 & Amblyomma americanum \\
\hline 10AVB-PAR0193 & TGBT003-10 & KX360414 & Amblyomma americanum \\
\hline 10AVB-PAR0194 & TGBT004-10 & KX360392 & Dermacentor variabilis \\
\hline 10AVB-PAR0195 & TGBT005-10 & KX360418 & Dermacentor variabilis \\
\hline 10AVB-PAR0196 & TGBT006-10 & KX360389 & Dermacentor variabilis \\
\hline 10AVB-PAR0198 & TGBT007-10 & KX360386 & Dermacentor variabilis \\
\hline 10AVB-PAR0199 & TGBT008-10 & KX360334 & Amblyomma americanum \\
\hline 10AVB-PAR0200 & TGBT009-10 & KX360362 & Amblyomma americanum \\
\hline 10AVB-PAR0201 & TGBT010-10 & KX360352 & Amblyomma americanum \\
\hline 10AVB-PAR0202 & TGBT011-10 & KX360335 & Amblyomma americanum \\
\hline 10AVB-PAR0203 & TGBT012-10 & KX360419 & Amblyomma americanum \\
\hline 10AVB-PAR0204 & TGBT013-10 & KX360350 & Amblyomma americanum \\
\hline
\end{tabular}




\begin{tabular}{llll} 
10AVB-PAR0205 & TGBT014-10 & KX360401 & Amblyomma americanum \\
\hline KCM025 & PAVOC027-13 & KX360355 & Ixodes spinipalpis \\
\hline KCM032 & PAVOC033-13 & KX360397 & Ixodes angustus \\
\hline KCM034 & PAVOC034-13 & KX360406 & Ixodes angustus \\
\hline KCM037 & PAVOC035-13 & KX360411 & Ixodes angustus \\
\hline KCM039 & PAVOC040-13 & KX360357 & Ixodes uriae \\
\hline KM028 & PAVOC029-13 & KX360349 & Dermacentor variabilis \\
\hline KM029 & PAVOC030-13 & KX360394 & Dermacentor variabilis \\
\hline KM030 & PAVOC031-13 & KX360348 & Dermacentor variabilis \\
\hline
\end{tabular}




\begin{tabular}{|c|c|c|c|c|c|}
\hline Life stage & Collection Date & Country & State/ Province & Region & Latitude \\
\hline nymph & $10-$ Sep- 09 & Canada & $\mathrm{ON}$ & Long Point & 42.592 \\
\hline female & 20-Mar-1C & Canada & $\mathrm{ON}$ & Toronto & 43.761 \\
\hline nymph & $\mathrm{N} / \mathrm{A}$ & Canada & $\mathrm{ON}$ & Turkey Point & 42.698 \\
\hline nymph & 20 -Oct-0S & Canada & $\mathrm{ON}$ & Turkey Point & 42.698 \\
\hline nymph & $\mathrm{N} / \mathrm{A}$ & Canada & $\mathrm{ON}$ & Welland & 42.993 \\
\hline female & 18-May-0 & Canada & $\mathrm{ON}$ & Wellesley & 43.477 \\
\hline female & 18-Apr-08 & Canada & $\mathrm{ON}$ & Turkey Point & 42.698 \\
\hline adult & 7-Jun- 07 & Canada & $\mathrm{ON}$ & Toronto & 43.653 \\
\hline female & 25-Jul-07 & Canada & $\mathrm{ON}$ & Muskoka & 44.902 \\
\hline female & 3-Jun-02 & Canada & $\mathrm{ON}$ & Burlington & 43.326 \\
\hline larva & 1-Jul-01 & Canada & NB & St. Andrews & 45.559 \\
\hline adult & $3-A p r-02$ & Canada & $\mathrm{ON}$ & Stoney Creek & 43.219 \\
\hline female & 25-Jul-01 & Canada & $\mathrm{NB}$ & St. Andrews & 45.558 \\
\hline female & 3-Jun-02 & Canada & $\mathrm{ON}$ & Georgetown & 43.65 \\
\hline female & 21-May-02 & Canada & $\mathrm{ON}$ & Chesterville & 45.103 \\
\hline male & $\mathrm{N} / \mathrm{A}$ & Canada & $\mathrm{BC}$ & Victoria & 48.429 \\
\hline female & 19-May-08 & Canada & $\mathrm{ON}$ & Highland & 47.6 \\
\hline male & $\mathrm{N} / \mathrm{A}$ & $\begin{array}{l}\text { United } \\
\text { States } \\
\end{array}$ & $\mathrm{CA}$ & Willits & 39.55 \\
\hline female & $\mathrm{N} / \mathrm{A}$ & Canada & $\mathrm{BC}$ & Hope & 49.385 \\
\hline female & $\mathrm{N} / \mathrm{A}$ & Canada & MB & Delta Beach & 50.187 \\
\hline
\end{tabular}




\begin{tabular}{|c|c|c|c|c|c|}
\hline nymph & & 21-Jun-00 Canada & SK & Acerage & 52.134 \\
\hline nymph & & 21-Jun-00 Canada & SK & Acerage & 52.134 \\
\hline female & & 16-Apr-98 Canada & $\mathrm{ON}$ & Long Point & 42.592 \\
\hline male & N/A & $\begin{array}{l}\text { United } \\
\text { States }\end{array}$ & GA & Geogian Southern University & 32.419 \\
\hline nymph & & 18-May-99 Canada & ON & Long Point & 42.592 \\
\hline nymph & & 5-Jun-07 Canada & $\mathrm{ON}$ & Toronto & 43.653 \\
\hline female & & 25-May-04 Canada & YT & Watson Lake & 60.065 \\
\hline nymph & & 27-May-08 Canada & QC & Ste-Anne-de-Bellevue & 45.404 \\
\hline male & N/A & Canada & $\mathrm{ON}$ & Bobcageon & 44.545 \\
\hline nymph & N/A & Canada & $\mathrm{ON}$ & Bobcageon & 42.592 \\
\hline nymph & & 22-Sep-04 Mexico & & Ekbalam & 20.887 \\
\hline nymph & & 24-Apr-01 Canada & $\mathrm{MB}$ & Delta Beach & 50.187 \\
\hline larva & & 9-Jan-01 Canada & $\mathrm{ON}$ & Mount Albert & 45.603 \\
\hline nymph & & 26-May-04 Canada & $\mathrm{ON}$ & Long Point & 42.592 \\
\hline nymph & & 9-Jan-97 Costa Ric & & Tarcoles & 9.773 \\
\hline nymph & N/A & Canada & $\mathrm{ON}$ & Long Point & 42.592 \\
\hline gravid female & & 14-Jun-99 Canada & $\mathrm{ON}$ & Elora & 43.683 \\
\hline female & & 2-Sep-11 Canada & $\mathrm{BC}$ & Rocky Point & 48.429 \\
\hline nymph & & 19-Aug-94 Canada & $\mathrm{ON}$ & Fort Erie & 42.902 \\
\hline nymph & N/A & Canada & $\mathrm{ON}$ & Kenora & 49.767 \\
\hline female & & 12-Aug-94 Canada & $\mathrm{ON}$ & Halton Hills & 43.642 \\
\hline nymph & & 19-Aug-94 Canada & ON & Fort Erie & 42.902 \\
\hline
\end{tabular}




\begin{tabular}{|c|c|c|c|c|c|}
\hline larva & & 14-Oct-08 Canada & $\mathrm{BC}$ & Victoria & 48.429 \\
\hline female & & 15-May-10 Canada & $\mathrm{AB}$ & Cypress Hills & 49.64 \\
\hline nymph & & 27-Apr-07 Canada & $\mathrm{ON}$ & Long Point & 42.597 \\
\hline nymph & & 27-Apr-07 Canada & $\mathrm{ON}$ & Long Point & 42.597 \\
\hline nymph & & 22-May-97 Canada & $\mathrm{ON}$ & Kenora & 49.767 \\
\hline female & & 18-Apr-12 Canada & $\mathrm{BC}$ & Kelowna & 49.953 \\
\hline male & & 11-May-12 Canada & $\mathrm{BC}$ & Kelowna & 49.953 \\
\hline female & & 16-May-12 Canada & $\mathrm{BC}$ & Kelowna & 49.953 \\
\hline female & N/A & Canada & $\mathrm{ON}$ & Sarnia & 42.985 \\
\hline male & & 10-Aug-92 Canada & ON & Sarnia & 42.985 \\
\hline adult & & 13-Jul-93 Canada & $\mathrm{ON}$ & Kincardine & 44.175 \\
\hline male & & 25-May-93 Canada & ON & Rondeau & 42.293 \\
\hline male & $\mathrm{N} / \mathrm{A}$ & Canada & $\mathrm{ON}$ & Keewatin & 49.767 \\
\hline nymph & & 12-Jul-94 Canada & $\mathrm{ON}$ & Kenora & 49.767 \\
\hline adult & & 23-Jun-94 Canada & $\mathrm{ON}$ & Morrisburg & 44.901 \\
\hline female & & 9-Jun-95 Canada & $\mathrm{ON}$ & Kenora & 49.767 \\
\hline male & & 27-May-96 Canada & $\mathrm{ON}$ & Thunder Bay & 48.416 \\
\hline adult & & 30-May-96 Canada & $\mathrm{ON}$ & Mount St. Marie & 46.813 \\
\hline adult & & 25-May-98 Canada & $\mathrm{ON}$ & Kingsville & 49.767 \\
\hline adult & & 7-May-98 Canada & $\mathrm{ON}$ & Hamilton & 43.244 \\
\hline adult & & 11-Jun-99 Canada & $\mathrm{ON}$ & Hensall & 43.434 \\
\hline adult & & 23-Jun-99 Canada & $\mathrm{ON}$ & Timmins & 48.476 \\
\hline
\end{tabular}




\begin{tabular}{|c|c|c|c|c|}
\hline adult & 26-May-99 Canada & $\mathrm{ON}$ & Londesborough & 43.729 \\
\hline adult & 25-Sep-00 Canada & $\mathrm{ON}$ & Maidstone & 42.209 \\
\hline adult & 24-May-00 Canada & $\mathrm{ON}$ & Wainfleet & 42.922 \\
\hline gravid female & 20-Jul-02 Canada & $\mathrm{ON}$ & Fort Erie & 42.902 \\
\hline adult & 20-Dec-02 Canada & $\mathrm{ON}$ & Toronto & 43.653 \\
\hline nymph & 9-Sep-02 Canada & $\mathrm{ON}$ & Kincardine & 44.175 \\
\hline adult & 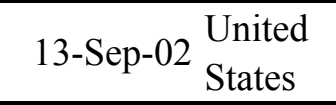 & KY & Lebanon & 37.555 \\
\hline Immature & 20-Aug-08 Canada & $\mathrm{AB}$ & Kananaskis & 50.7649 \\
\hline Immature & 20-Aug-08 Canada & $\mathrm{AB}$ & Kananaskis & 50.7649 \\
\hline Immature & 30-Mar-10 $\begin{array}{l}\text { United } \\
\text { States }\end{array}$ & FL & Tarkiln Bayou SP & 30.367 \\
\hline Immature & 28-Mar-10 $\begin{array}{l}\text { United } \\
\text { States }\end{array}$ & $\mathrm{FL}$ & Ocala Nat Forest & 30.3154 \\
\hline Immature & 28-Mar-10 $\begin{array}{l}\text { United } \\
\text { States }\end{array}$ & $\mathrm{FL}$ & Ocala Nat Forest & 30.3154 \\
\hline Adult & $\begin{array}{ll}\text { 17-May-10 United } \\
\text { States }\end{array}$ & $\mathrm{CO}$ & $\mathrm{N} / \mathrm{A}$ & 35.6937 \\
\hline Adult & 17-May-10 $\begin{array}{l}\text { United } \\
\text { States }\end{array}$ & $\mathrm{CO}$ & $\mathrm{N} / \mathrm{A}$ & 35.6937 \\
\hline Adult & $\begin{array}{ll}\text { 17-May-10 } & \begin{array}{l}\text { United } \\
\text { States }\end{array} \\
\end{array}$ & $\mathrm{CO}$ & N/A & 35.6937 \\
\hline Adult & 17-May-10 $\begin{array}{l}\text { United } \\
\text { States }\end{array}$ & $\mathrm{AR}$ & $\mathrm{N} / \mathrm{A}$ & 35.3666 \\
\hline Adult & 26-Mar-10 $\begin{array}{l}\text { United } \\
\text { States }\end{array}$ & $\mathrm{FL}$ & Ocala Nat Forest & 29.2631 \\
\hline Adult & 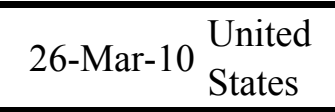 & FL & Ocala Nat Forest & 29.2631 \\
\hline Adult & 27-Mar-10 $\begin{array}{l}\text { United } \\
\text { States }\end{array}$ & FL & Ocala Nat Forest & 29.1824 \\
\hline Adult & $\begin{array}{ll}27-M a r-10 & \begin{array}{l}\text { United } \\
\text { States }\end{array} \\
\end{array}$ & FL & Ocala Nat Forest & 29.1824 \\
\hline Adult & $\begin{array}{ll}\text { 27-Mar-10 } & \begin{array}{l}\text { United } \\
\text { States }\end{array} \\
\end{array}$ & $\mathrm{FL}$ & Ocala Nat Forest & 29.1824 \\
\hline Adult & 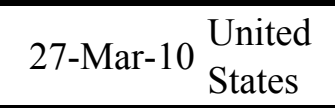 & FL & Ocala Nat Forest & 29.1824 \\
\hline
\end{tabular}




\begin{tabular}{|c|c|c|c|c|c|}
\hline Immature & & 27-Mar-10 $\begin{array}{l}\text { United } \\
\text { States }\end{array}$ & FL & Ocala Nat Forest & 29.1824 \\
\hline N/A & & 7-Feb-13 Canada & $\mathrm{BC}$ & Vancouver Island & 48.4544 \\
\hline Nymph & $\mathrm{N} / \mathrm{A}$ & Canada & $\mathrm{BC}$ & $\mathrm{N} / \mathrm{A}$ & 48.3667 \\
\hline Adult & $\mathrm{N} / \mathrm{A}$ & Canada & $\mathrm{BC}$ & $\mathrm{N} / \mathrm{A}$ & 48.3667 \\
\hline Adult & $\mathrm{N} / \mathrm{A}$ & Canada & $\mathrm{BC}$ & $\mathrm{N} / \mathrm{A}$ & 48.3667 \\
\hline Adult & & 2-Aug-13 Canada & NL & $\mathrm{N} / \mathrm{A}$ & 53.934 \\
\hline Nymph & $\mathrm{N} / \mathrm{A}$ & Canada & $\mathrm{BC}$ & $\mathrm{N} / \mathrm{A}$ & 48.3667 \\
\hline Adult & & 29-Jun-13 Canada & MB & Riding Mountain National Park & 50.7251 \\
\hline N/A & & 29-Jun-13 Canada & MB & Riding Mountain National Park & 50.7251 \\
\hline Adult & & 28-Jun-13 Canada & MB & Riding Mountain National Park & 50.6793 \\
\hline
\end{tabular}




\begin{tabular}{|c|c|}
\hline Longitude & Accuracy $(\mathbf{k m})$ \\
\hline-80.447 & 1 \\
\hline-80.447 & 1 \\
\hline-80.331 & 25 \\
\hline-80.331 & 1 \\
\hline-79.239 & 25 \\
\hline-80.764 & 25 \\
\hline-80.331 & 1 \\
\hline-79.383 & 1 \\
\hline-79.576 & 50 \\
\hline-79.799 & 25 \\
\hline-61.89 & 25 \\
\hline-79.766 & 25 \\
\hline-61.89 & 25 \\
\hline-79.904 & 25 \\
\hline-75.23 & 25 \\
\hline-123.366 & 25 \\
\hline-79.816 & 25 \\
\hline-123.438 & 100 \\
\hline-121.441 & 25 \\
\hline-98.32 & 1 \\
\hline
\end{tabular}




\begin{tabular}{lr}
\hline-106.648 & 25 \\
\hline-106.648 & 25 \\
\hline-80.447 & 1 \\
\hline-81.787 & 1 \\
\hline-80.447 & 1 \\
\hline-79.383 & 25 \\
\hline-128.703 & 25 \\
\hline-73.95 & 25 \\
\hline-78.541 & 25 \\
\hline-80.447 & 25 \\
\hline-88.137 & 25 \\
\hline-98.32 & 100 \\
\hline-75.835 & 25 \\
\hline-80.447 & 25 \\
\hline-89.94 .95 \\
\hline-80.447
\end{tabular}

https://mc06.manuscriptcentral.com/genome-pubs 


\begin{tabular}{|c|c|}
\hline-110.19 & 1 \\
\hline-80.45 & 1 \\
\hline-80.45 & 1 \\
\hline-94.489 & 25 \\
\hline-119.375 & 50 \\
\hline-119.375 & 50 \\
\hline-119.375 & 50 \\
\hline-82.36 & 25 \\
\hline-82.36 & 25 \\
\hline-81.636 & 25 \\
\hline-82.134 & 1 \\
\hline-94.55 & 25 \\
\hline-94.489 & 25 \\
\hline-75.185 & 25 \\
\hline-94.489 & 25 \\
\hline-89.267 & 100 \\
\hline-71.176 & 25 \\
\hline-94.489 & 25 \\
\hline-79.889 & 25 \\
\hline-81.503 & 25 \\
\hline-81.33 & 25 \\
\hline
\end{tabular}

https://mc06.manuscriptcentral.com/genome-pubs 


\begin{tabular}{cr}
-81.465 & 50 \\
\hline-82.888 & 25 \\
\hline-79.375 & 25 \\
\hline-78.972 & 25 \\
\hline-79.383 & 25 \\
\hline-81.636 & 25 \\
\hline-85.391 & 25 \\
\hline-115.143 N/A & \\
\hline-115.143 N/A \\
\hline-87.4071 N/A
\end{tabular}

$-87.4214 \mathrm{~N} / \mathrm{A}$

$-87.4214 \mathrm{~N} / \mathrm{A}$

$-101.573 \mathrm{~N} / \mathrm{A}$

$-101.573 \mathrm{~N} / \mathrm{A}$

$\begin{array}{r}\hline-101.573 \mathrm{~N} / \mathrm{A} \\ \hline-93.344 \mathrm{~N} / \mathrm{A} \\ \hline\end{array}$

$-81.8552 \mathrm{~N} / \mathrm{A}$

-81.8552 N/A

$-81.7133 \mathrm{~N} / \mathrm{A}$

$-81.7133 \mathrm{~N} / \mathrm{A}$

$-81.7133 \mathrm{~N} / \mathrm{A}$

$-81.7133 \mathrm{~N} / \mathrm{A}$ 
$-81.7133 \mathrm{~N} / \mathrm{A}$

\begin{tabular}{lr}
\hline-123.458 & 25 \\
\hline-123.707 & 25 \\
\hline-123.707 & 25 \\
\hline-123.707 & 25 \\
\hline-56.505 & 25 \\
\hline-123.707 & 25 \\
\hline-99.5553 N/A & \\
\hline-99.5553 N/A & \\
\hline-99.8942 N/A
\end{tabular}

